\title{
High mammal species turnover in forest patches immersed in biofuel plantations
}

\author{
Gabrielle Beca ${ }^{a}$, Maurício H. Vancine ${ }^{\mathrm{a}}$, Carolina S. Carvalho ${ }^{\mathrm{a}}$, Felipe Pedrosa ${ }^{\mathrm{a}}$, Rafael Souza C. Alves ${ }^{\mathrm{a}}$, \\ Daiane Buscariol ${ }^{\mathrm{a}}$, Carlos A. Peres ${ }^{\mathrm{b}}$, Milton Cezar Ribeiro ${ }^{\mathrm{a}}$, Mauro Galetti ${ }^{\mathrm{a}, \mathrm{c}, *}$ \\ a Departamento de Ecologia, Instituto de Biociências, Universidade Estadual Paulista (UNESP), 13506-900 Rio Claro, São Paulo, Brazil \\ b Center for Ecology, Evolution and Conservation, School of Environmental Sciences, University of East Anglia (UEA), Norwich Research Park, NR47TJ, Norwich, UK

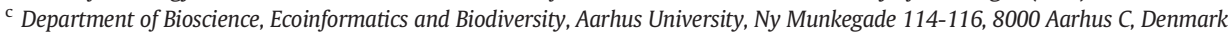

\section{A R T I C L E I N F O}

\section{Article history:}

Received 8 October 2016

Received in revised form 30 January 2017

Accepted 19 February 2017

Available online 2 March 2017

\section{Keywords:}

Defaunation

Extinction risk

Forest fragmentation

Sugarcane matrix

Species turnover

Camera trapping

\begin{abstract}
A B S T R A C T
Remnant habitat patches immersed within biofuel cropland matrices can retain considerable species diversity, although the effects of land use change on species persistence in historically modified landscapes remain unclear. The Atlantic Forest is one of the most fragmented South American biodiversity hotspots and retains about $12 \%$ of its original vegetation cover. Most of these remnants are distributed in small isolated fragments immersed mainly within pastures and sugarcane monocultures. Here we examine how species richness and composition of medium and large-sized mammals are explained by forest cover, structural area and forest edge amount at the landscape scale. We sampled 22 fragmented landscapes dominated by sugarcane plantations along a wide gradient of forest cover (3\% to 96\%) in southeastern Brazil. We recorded $88 \%$ of terrestrial mammal species expected for this region, but many likely local extirpations were detected at the landscape scale, with losses between $50 \%$ to $80 \%$ of species. Most of the landscapes were highly depleted of forest-specialist species, with replacements by exotics and/or species typical of non-forest habitats. We found that total mammalian species richness, which includes forest-specialists, generalists, exotics and non-forest dwelling species, was not affected by landscape metrics, such as forest cover, structural area and forest edge amount. Nevertheless, forest cover was important predictor of the presence of three ungulates, a medium-sized rodent, and an armadillo. Local mammalian communities exhibited a high degree of species turnover between landscapes, representing $95 \%$ of the total $\beta$-diversity. In this region, where there was no regional extinction, landholder compliance with the Brazilian Forest Bill and restoration measures will enhance habitat connectivity and mammal persistence across the wider unprotected countryside.
\end{abstract}

(C) 2017 Elsevier Ltd. All rights reserved.

\section{Introduction}

The replacement of native vegetation by agriculture, pastures and urban areas is a central conservation concern throughout the tropics (Schipper et al., 2008). Land conversion to agricultural ecosystems accounts for $80 \%$ of deforestation globally (Kissinger et al., 2012), and is the leading driver of current rates of global biodiversity loss (Tscharntke et al., 2005; Green et al., 2005), and degradation of ecosystem functioning and services (Turner et al., 2007). About 53\% of all assessed terrestrial vertebrates are threatened due to the negative impacts of agricultural intensification (Ceballos et al., 2015). These impacts have already been documented at regional and landscape scale for insects (Benton et al., 2002), birds (Donald et al., 2001), and mammals (Muylaert et al., 2016; Ribeiro et al., 2016).

Due to the current energy crisis, emergent developing countries have shown growing interests in biofuel production. Sugarcane

\footnotetext{
* Corresponding author.

E-mail address: mgaletti@rc.unesp.br (M. Galetti).
}

(Saccharum spp.) is cultivated in over 100 countries and represents one of the major biofuel crops worldwide. In most tropical areas, native forest remnants largely persist within private landholdings, embedded within matrices of sugarcane and pasture (Tabarelli et al., 2004). These agricultural areas act as a selective filter on animal movements across the landscape (Gascon et al., 1999; Chiarello, 2000), affecting matrix fluxes according to the dispersal capacity of each species (Lees and Peres, 2009). As such, highly resilient species gradually dominate ecological communities at the expense of native species that do not tolerate high levels of human disturbances (Tabarelli et al., 2012). This variation in community composition can result in either the reduction or increase in beta-diversity across multiple spatial scales (Wearn et al., 2016). Habitat fragmentation induced by agricultural expansion can also lead to species extinctions or population collapses due to edge effects (LyraJorge et al., 2010), characterized by rapid biotic and abiotic transitions from forest areas to adjacent agricultural systems (Laurance et al., 2002). Forest edges can also influence native species responses to habitat changes (Lyra-Jorge et al., 2010), as they facilitate access to domestic dogs and other invasive predators and competitors into fragments, resulting in the reorganization of native assemblages (Lessa et al., 2016). 
The Brazilian Atlantic Forest is an ideal study system to understand the long-term impacts of human activities on natural areas. Only $12 \%$ of the original Atlantic Forest vegetation cover currently persists, $84 \%$ of which consisting of forest remnants smaller than 50 ha (Ribeiro et al., 2009). These remnants are mostly isolated due to agricultural expansion, influencing the number of species that can survive within fragments (Magioli et al., 2015). The combined effects of these multiple factors have resulted in high levels of defaunation throughout the Atlantic Forest (Canale et al., 2012; Galetti et al., 2016a), especially the loss of large-bodied vertebrates, which may lead to severe consequences in forest composition and function through ecological cascades (Dirzo et al., 2014; Young et al., 2016).

Due to the negative effects of habitat alteration on biodiversity, there is an urgent need for information regarding the potential consequences of increased agricultural expansion on wildlife. In addition, there is an urgent need to evaluate the role of small forest patches in conservation planning. Here we set out to explain the species richness and composition of medium and large-sized mammals in fragmented forest landscapes dominated by sugarcane plantations. We aim to identify how landscape structure influences the number, composition and beta-diversity of mammal species across these landscapes. We therefore address three related hypotheses: (1) overall habitat amount is a robust proxy of habitat loss and should be a good predictor of mammal species richness (Andrén, 1994; Pardini et al., 2010; Fahrig, 2013). We should therefore expect higher overall species richness in response to the total amount of remaining natural habitat. On the other hand, (2) the amount of forest edge should have a neutral or ambivalent effect on mammal species richness, since it can either benefit generalists adapted to disturbed habitats or be detrimental to forest-specialists that are more sensitive to habitat loss and fragmentation (Kremsater and Bunnell, 1999; Lyra-Jorge et al., 2010). We also expect that (3) mammal communities embedded in a sugarcane matrix should experience a process of nestedness (Baselga, 2010), due to habitat loss and fragmentation, that leads to deterministic species losses, thereby creating nested species subsets of the larger community (Fernández-Juricic, 2002). Finally, we propose restoration measures to enhance connectivity, especially in landscapes containing greater amounts of forest cover and low opportunity-cost matrix habitats, such as abandoned cattle pastures to boost local mammal diversity.

\section{Material and methods}

\subsection{Study area}

This study was carried out at 22 anthropogenic landscapes (of 1257 ha each) dominated by sugarcane plantations distributed in a large ( $450 \mathrm{~km}$ to $500 \mathrm{~km}$ ) region of semideciduous seasonal forest remnants in the state of São Paulo, Brazil (Fig. 1). The state of São Paulo is

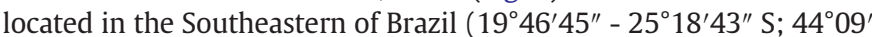
$\left.38^{\prime \prime}-53^{\circ} 06^{\prime} 35^{\prime \prime} \mathrm{W}\right)$, has an area of approximately $248.210 \mathrm{~km}^{2}$, and a population of about 42 million (21.5\% of the Brazilian population).

We selected the landscapes using a recent map of forest remnants of southeastern Brazil, which was derived from $30 \mathrm{~m}$ spatial resolution Landsat 5 images at the scale 1:25,000, and corrected using Google Earth images using the Open Layer plug-in within QGIS 1.8.0 (QGIS Development Team 2014). Albers Projection and SAD69 Datum were used to organize the spatial database. Although the original vegetation of the state of São Paulo is highly heterogeneous, we restricted sampling to semideciduous forest remnants only. These forests are the most threatened forest type in the whole biome, with only $7 \%$ of the vegetation was left (Ribeiro et al., 2009). These forests differ from dense ombrophilous (evergreen) forest due to the combination of rainfall gradients that becomes more seasonal farther from the ocean, elevation and temperature, which change in montane areas (Salis et al., 1995). This forest type holds 31 species of medium and large size terrestrial mammal species (Cullen et al., 2004; Galetti et al., 2009). These landscapes ensured a wide gradient of forest cover (from 3\% to $96 \%$ considering a $2 \mathrm{~km}$ buffer around the landscape centroids) and a dominant matrix type consisting of sugarcane monoculture. We selected this spatial extent because large vertebrate responses to landscape metrics were best explained at the $2 \mathrm{~km}$ spatial extent (Lyra-Jorge et al., 2010). To minimize spatial autocorrelation between our study landscapes, the external boundaries of their buffer zones were spaced apart by at least $10 \mathrm{~km}$ (Fortin and Dale, 2005).

\subsection{Mammal sampling}

We used two main sampling techniques - camera trapping and sign surveys - to assess species richness and composition of medium to large-sized mammals ( $\geq 1 \mathrm{~kg}$, see Srbek-Araujo and Chiarello, 2005). We selected these methods because they can record species with a wide range of ecological and behavioral characteristics and activity periods (i.e. diurnal, nocturnal and cathemeral). Surveys using camera traps were carried out from January 2014 to September 2015, using eight unbaited cameras per landscape, that were placed at different positions, which could be in the same fragment or in different fragments, depending on the patch size of the central forest remnant within each $2 \mathrm{~km}$ radius buffer. We used a mosaic-level sampling protocol with sample points restricted to semideciduous forest, while attempting to sample the most number of fragments within each landscape, rather than just one (Bennett et al., 2006). The camera traps were exposed over a period of 30 days and spaced apart by distances ranging from $200 \mathrm{~m}$ to $1500 \mathrm{~m}$. Cameras were installed on tree trunks at $30 \mathrm{~cm}$ above ground at sites with similar local features (e.g. local animal activity, such as natural tracks, but avoiding roads). Sampling effort at each landscape was standardized at 240 camera trap/days (5760 camera trap/hours). Animal sign surveys included systematic searches for fecal material, tracks, burrows and carcasses, all of which were carried out along the edge of each of the sampled fragments within all 22 landscapes.

\subsection{Landscape metrics}

For each landscape, we calculated the forest cover (\%), the amount of forest edges (ha), and the structural area (ha) of the fragments. Forest cover and forest edge amount were calculated within a radial buffer of $2 \mathrm{~km}$ (Supplementary Material, Fig. S1). Forest cover (\%) was calculated by considering the area of all remaining semideciduous forest patches within the $2 \mathrm{~km}$ buffer, divided by the landscape size and multiplied by 100 . To calculate forest edge amount, we first selected all peripheral $30 \mathrm{~m}$ forest pixels from our raster map from the forest-matrix boundary of all fragments in each landscape, considering the entire $2 \mathrm{~km}$ buffer around all fragments, and then calculated their aggregate area. Assuming that terrestrial mammals can move beyond the boundaries of the $2 \mathrm{~km}$ buffer area, particularly when forest patches straddled this boundary, we defined the structural area as the cumulative fragment area that was intercepted by the $2 \mathrm{~km}$ buffer within another buffer of $10 \mathrm{~km}$ radius (see Supplementary Material, Fig. S1). To check for collinearity between explanatory variables, we then calculated the correlation matrix between all landscape metrics, but none of which were strongly inter-correlated (Pearson's $r<0.7$; Zar, 2010). We also used Mantel tests (Fortin and Dale, 2005) to check if the species richness values across our 22 study landscapes presented spatial autocorrelation.

We used a set of CBERS 2B (spatial resolution of 20 and $3 \mathrm{~m}$ ) and Landsat 7 (spatial resolution of $30 \mathrm{~m}$ ) imagery to aid in the process of landscape selection. We used a set of CBERS 2B (spatial resolution of 20 and $3 \mathrm{~m}$ ) and Landsat 7 (spatial resolution of $30 \mathrm{~m}$ ) imagery to aid in the process of landscape selection.

\subsection{Data analysis}

\subsubsection{Total species richness}

We define total mammal species richness as the number of species recorded at each of our 22 landscapes. To examine the degree to 


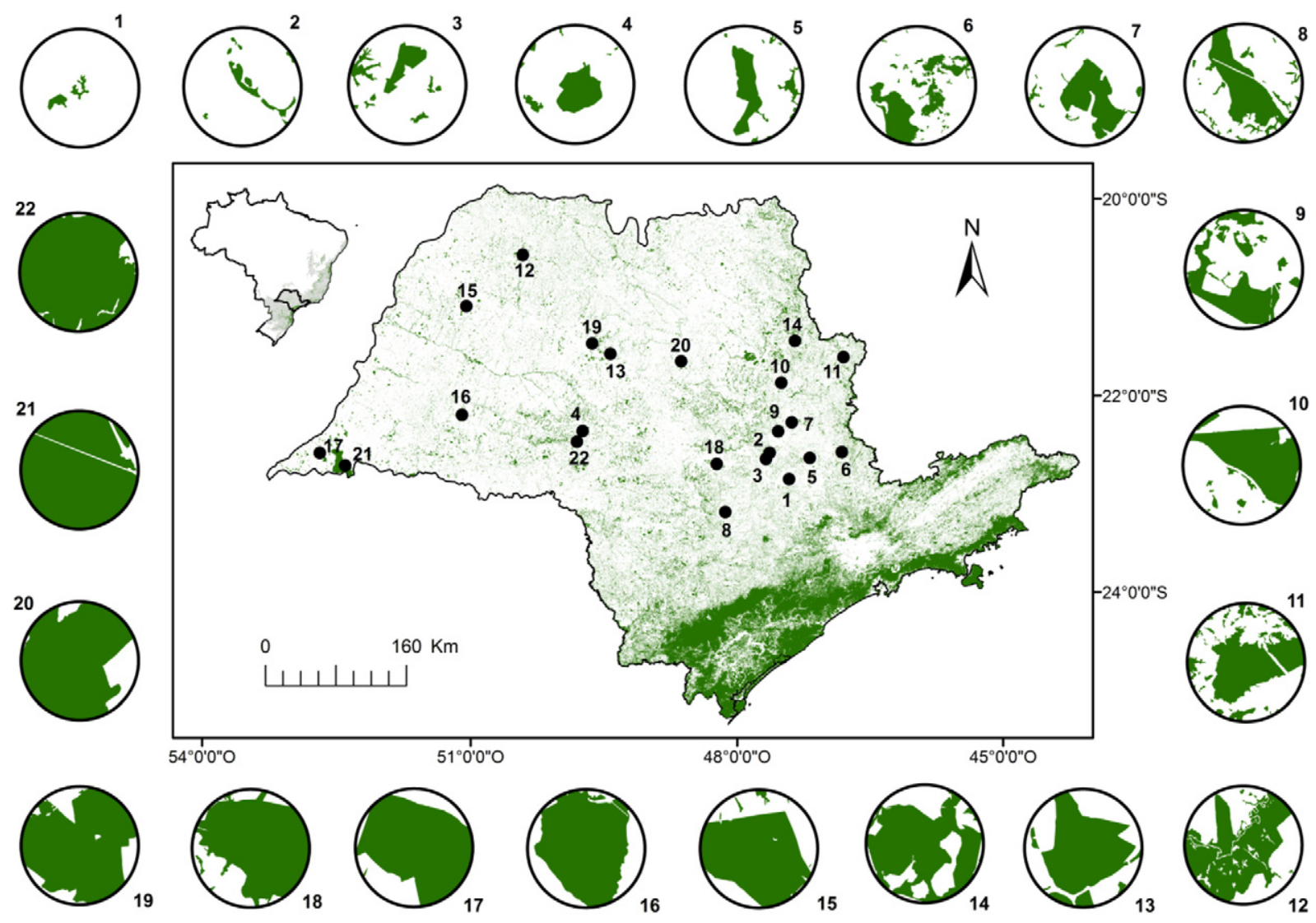

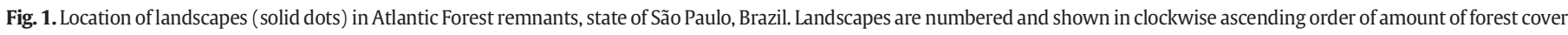
(green). Black circles indicate $2 \mathrm{~km}$ radial buffers around the centroid of each landscape.

which sampling effort was sufficient at each landscape, we constructed species accumulation curves, seeking to reach an asymptote, based on the number of days sampled and the number of species recorded per landscape (Gotelli and Colwell, 2001). Accumulation curves were generated using the the specaccum function and the rarefaction method, and the specpool function (Oksanen et al., 2013), both available at 'vegan' package of R. Results were compared with the predictions of the "firstorder Jackknife" estimator (Jackknife 1), which estimates the expected species richness at each sampled landscape (Smith and Pontius, 2006). This is a non-parametric estimator based on the number of unique species contained in each observation (Smith and Pontius, 2006), which performs better than other estimators for datasets derived from large numbers of camera-days (Tobler et al., 2008). We also selected this estimator because it is less biased and based on species presence or absence, rather than on species abundance (Smith and Pontius, 2006).

\subsubsection{Richness of forest-specialists}

To restrict part of the analysis to forest-specialist species, we excluded exotic species (domestic dog and wild boar), aquatic habitat specialists (capybara, paca, and crab-eating raccoon), and non-forest dwelling mammals (white-eared opossum, tree porcupine, giant anteater, collared anteater, crab-eating fox, maned wolf and brown brocket deer). We did it because sample areas near watercourses or non-forest habitats were beyond the scope of this study. To classify the species we considered their preferred habitat types, life history, locomotion, morphology, feeding habits and behavior (Magioli et al., 2015; Supplementary Material, Table S5).

\subsubsection{Landscape effects on mammal}

We related both total mammal species richness and richness of forest-specialists to the explanatory landscape metrics (forest cover, structural area, and forest edge amount). We used generalized linear models (GLMs), with a Poisson error distribution to examine species richness (Zuur et al., 2009). We selected the most plausible models using Akaike's weights (wAICc) and the $\triangle A I C c$, corrected for small sample sizes. Four models, one per landscape metrics, were used as competing models for explain the patterns. Additionally we included a null model, which represent the absence of effect, on the list of competing models. We considered that models with $\triangle$ AICc $<2.0$ and wAICC $>0.1$ are equally plausible to explain observed patterns (Burnham and Anderson, 2002).

We performed a redundancy analysis (RDA) to evaluate how the landscape structure affected the species composition of medium and large-sized mammals, using the 'vegan' package (Oksanen et al., 2013) in $\mathrm{R}$, and the rda function (Borcard et al., 2011; Legendre and Legendre, 2012). This analysis is based on how the predictor matrix (landscape metrics) may influence the response matrix (mammal species composition). In light of associative results provided by the RDA, we then related a set of selected species to the explanatory landscape metrics, also using GLMs and a binomial error structure and a logit link function for presence/absence data (Zuur et al., 2009), and the model selection approach as described above.

\subsubsection{Beta-diversity}

We calculated the species $\beta$-diversity values among landscapes using the Sørensen dissimilarity index, which was decomposed into its species turnover and nestedness components (Baselga, 2010). The species spatial turnover is represented by Simpson dissimilarity index $\left(\beta_{\text {sim }}\right)$ and nestedness is represented by the nestedness index $\left(\beta_{\text {nes }}\right)$, which quantifies the pairwise dissimilarity due to differences in species richness (Baselga, 2010). Turnover occurs when species present at any given site are absent at another site, but replaced by another species 
absent from the first. Nestedness occurs when species present at a site are absent from another, but are not replaced by additional species. $\beta$-diversity was estimated using the 'betapart' package in $\mathrm{R}$ (Baselga and Orme, 2012). Additionally, we tested if the two $\beta$-diversity components ( $\beta_{\text {sim }}$ and $\beta_{\text {nes }}$ ) for landscape-level mammal assemblages differed from those expected by chance. For this purpose, we created a null model, preserving the rarity of species occurrence (i.e. by maintaining the number of times each species occurred at all 22 landscapes), and built confidence intervals for both $\beta_{\text {sim }}$ and $\beta_{\text {nes, }}$, whereby values outside those confidence intervals indicated divergence from random expectations.

We calculated the pairwise dissimilarity of landscape metrics among sites using Euclidean distances, calculated using the vegdist function within the vegan R package (Oksanen et al., 2013). We used Multiple Regressions on distance Matrices (MRM; see Lichstein, 2007) to examine the effects of landscape metrics on the two components of $\beta$-diversity. Here, $\beta$-diversity and its two components ( $\beta_{\text {sim }}$ and $\left.\beta_{\text {nes }}\right)$ were used as the response distance matrices, whereas landscape metrics and geographic distances were explanatory matrices. MRM can cope with linear, non-linear and non-parametric relationships between matrices, and is thought to be a more flexible approach than the often-used Mantel test. Finally, we tested the significance of $R^{2}$ values with 100 permutations. Estimates of MRM tests were carried out using the ecodist package in $\mathrm{R}$ (Goslee and Urban, 2007).

\subsubsection{Projecting forest habitat restoration}

Aiming to facilitate natural and/or assisted reforestation in any agropastoral area incurring low opportunity costs, we created a $10 \mathrm{~km}$ radial buffer around each of our 22 landscapes based on a recent forest map (Soares-Filho et al., 2016), a $500 \mathrm{~m}$ resolution and the Albers projection, using the SAD 69 Datum. We then distinguished five mutually exclusive land-cover classes - forest areas (including semideciduous forests and cerrado areas), urban centers, water bodies regardless of size, and areas of either low or high agricultural opportunity costs (low-intensity grazing and cropland areas, respectively). We then quantified the proportion of pixels within each land-use class for each landscape. We assume that degraded cattle pastures are more favorable for forest regeneration than alternative cropland areas, since the former accrue low revenue and are often abandoned, thereby inviting secondary succession where herbaceous, shrub and woody species gradually replace exotic grasses (Rocha et al., 2016). All imagery analyses were carried out using the raster package within $\mathrm{R}$ (Hijmans, 2016).

\section{Results}

\subsubsection{Mammal species richness}

Based on 126,720 camera-trapping hours, we recorded 29 of the potential species expected for the entire region, including two relatively ubiquitous exotic species: domestic dog (Canis lupus familiaris) and wild boar (Sus scrofa; Supplementary Material, Table S5), which were recorded at 12 and 10 of the 22 landscapes, respectively. On average, we recorded 11 mammal species per landscape, with a minimum of 7 and a maximum of 18 species. The most widespread species was the nine-banded armadillo (Dasypus novemcinctus), which was recorded at all landscapes, followed by coati (Nasua nasua; 15 landscapes) and raccoon (Procyon cancrivorus; 14 landscapes). The bush dog (Speothos venaticus) and tree porcupine (Coendou prehensilis) were the rarest species, both recorded only once, followed by white-lipped peccary (Tayassu pecari), which was recorded at only two landscapes (Table S5, see Fig. S3 for the proportion of species recorded at each landscape). Although the mean accumulation curve estimating species richness per survey-day failed to reach an asymptote, according to the first order jackknife the overall sampling effort was sufficient (Supplementary Material, Table S4).

\subsubsection{Landscape effects on mammal assemblages}

The three landscapes retaining the highest diversity of mammals (15 to 18 species) retained some of the highest levels of forest cover (55\% to $95 \%$ ). The two most impoverished landscapes, each of which with only seven species, retained only $16 \%$ to $45 \%$ of forest cover (Table S3).

We identified small but significant spatial autocorrelation of species richness $\left(R^{2}=0.27 ; p=0.004\right)$, across our 22 study landscapes. None of the metrics explained the total species richness per landscape, since the null model was among the best models explaining the variance in total species richness (Table 1 ). However, partial species richness, which considers mainly forest-specialists, was best explained by forest cover and structural area $(\triangle \mathrm{AICc}=0$, wAICc $=0.67$ and $\triangle \mathrm{AICc}=1.7$, wAICc $=$ 0.28 respectively, Table 1 , Fig. $\mathrm{S} 2$ ).

The RDA showed a significant relationship between mammal species composition and the landscape metrics $\left(R^{2}=0.20 ; p=0.007\right.$, Fig. 2$)$. The first ordination axis $\left(\mathrm{RDA}_{1}\right)$ explained $68 \%$ with the variation, for which forest cover, followed by the structural area, contributed most of the variance. The second ordination axis $\left(\mathrm{RDA}_{2}\right)$ explained $22 \%$ of the variation, and was primarily driven by forest edge amount.

Based on these results, we related species occurrence to landscape metrics using logistic regressions (Fig. 3, Table S1). The occurrence of tapir (Tapirus terrestris) and collared peccary (Pecari tajacu) was positively influenced by forest cover $(\triangle \mathrm{AICc}=0$, wAICc $=0.89$ and $\triangle \mathrm{AICc}=0$, wAICc $=0.83$, respectively), whereas forest edge amount had a positive influence on maned wolf (Chrysocyon brachyurus; $\triangle \mathrm{AICc}=0, \mathrm{wAICc}=0.94$ ). Although none of the species were positively associated with the structural area within the RDA, this metric best explained the occurrence of agouti (Dasyprocta azarae; $\triangle \mathrm{AICC}=1.9$, wAICc $=0.25$ ) and greater naked-tailed armadillo (Cabassous tatouay; $\triangle \mathrm{AICc}=0.6$, wAICc $=0.33$ ), that were also influenced by forest cover $(\triangle \mathrm{AICC}=0$, wAICc $=0.66$ and $\triangle \mathrm{AICC}=0$, wAICc $=0.45$ respectively; Table S1).

\subsubsection{Patterns of beta-diversity}

The variation in $\beta$-diversity among assemblages of medium and large-sized mammals was mainly explained by the species turnover $\left(\beta_{\text {sim }}, 95 \%\right)$, with only $5 \%$ of remaining variation explained by nestedness. All values differed from the expected distribution based on the null model, with $\beta_{\text {sim }}=0.817$, C.I.95\% $=[0.822,0.823]$ and $\beta_{\text {nes }}=0.041$, C.I.95\% $=[0.035,0.036]$. Both Sørensen dissimilarity index $\left(\beta_{\text {sor }}\right)$ and species turnover $\left(\beta_{\text {sim }}\right)$ were positively affected by the interaction with forest cover. On the other hand, patterns of nestedness $\left(\beta_{\text {nes }}\right)$ could not be explained by any of the landscape metrics (Supplementary Material, Table S2).

\subsubsection{Restoration opportunities within biofuel production areas}

Given the five land-cover classes we were able to distinguish within a $10 \mathrm{~km}$ buffer around each study landscape, we found large areas (range $=24-95 \%$ ) of low opportunity costs (farmland dominated by

\section{Table 1}

Summary of the set of candidate models fitted to the total and forest-specialist richness in response to landscape metrics at 22 semideciduous forest landscapes. The $\Delta \mathrm{AICc}$, df, and wAICc indicate the difference in corrected Akaike values, degrees of freedom of the model, and Akaike weights, respectively. Plausible models to explain each response variable are shown in bold.

\begin{tabular}{lllll}
\hline Response variable & Model & $\Delta$ AICc & df & wAICc \\
\hline Total richness & Null & & & \\
& Forest cover & $\mathbf{0 . 0}$ & 1 & $\mathbf{0 . 3 6}$ \\
& Structural area & $\mathbf{1 . 1}$ & 2 & $\mathbf{0 . 2 1}$ \\
& Forest edge amount & 2.4 & 2 & 0.11 \\
& & & & \\
Richness of forest-specialists & & & & \\
& Forest cover & $\mathbf{0 . 0}$ & 2 & $\mathbf{0 . 6 7}$ \\
& Structural area & $\mathbf{1 . 7}$ & 2 & $\mathbf{0 . 2 8}$ \\
& Null & 6.4 & 1 & 0.02 \\
& Forest edge amount & 7.6 & 2 & 0.01 \\
\hline
\end{tabular}




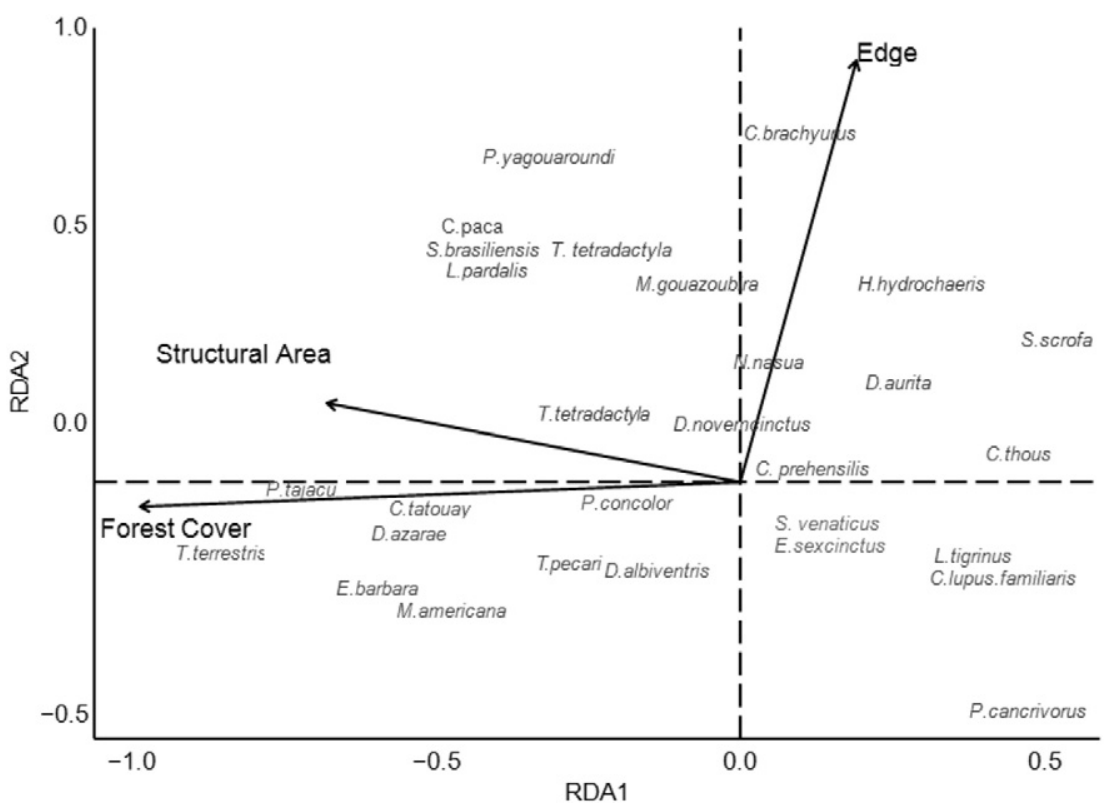

Fig. 2. RDA ordination of medium and large-sized terrestrial mammals in relation to landscape metrics at 22 landscapes of semideciduous forest in southeastern Brazil.

degraded pastures) within and around most of our 22 landscapes. These areas can be highly favorable to natural and/or assisted forest regrowth following pasture abandonment (Supplementary Material, Fig. S3). However, these land-use transitions can be constrained by competing takeovers from rural enterprises seeking to expand production areas, which in this region includes primarily sugarcane, citrus plantations and fast-growing tree monocultures (e.g. Eucalyptus spp.).

\section{Discussion}

Our results indicate that landscapes dominated by intensive agricultural land use, such as sugarcane monoculture, retained an impoverished fraction of the original assemblage of medium to largesized mammals, but collectively safeguarded a large part of the mammal fauna. We recorded $88 \%$ of the species expected to occur across the region (Cullen et al., 2004; Galetti et al., 2009), showing that there were no regional-scale extinctions considering all landscapes combined. However, there were many likely extirpations at the landscape scale, with losses between $50 \%$ to $80 \%$ of all mammal species. Moreover, we showed that losses in mammal species richness at these highly modified landscapes have been partly compensated by non-forest dwelling species, exotics, or both, since they tend to be more tolerant of habitat disturbance and are more adept at colonizing and persisting in highly degraded habitats typical of agricultural landscapes (Banks-Leite et al., 2014).

We did not record the jaguar (Panthera onca), margay (Leopardus wiedii), lesser grison (Galictis cuja) and the neotropical otter (Lontra longicaudis). The jaguar, an apex predator, is possibly absent in most of these landscapes (Jorge et al., 2013; Paviolo et al., 2016), but it still occurs in our landscape retaining the most amount of forest cover (Paviolo et al., 2016). The lesser grison, margay and neotropical otter also occur in the region (Cullen et al., 2004) but we failed to detect them in our sampling. Therefore, based on our study and previous surveys, the eastern region of the São Paulo state, where only $14 \%$ of forest cover persists, still retains all expected mammal species with no regional extinction.

We found that total species richness was unrelated to landscape metrics, such as forest cover, structural area and forest edge amount. This is largely because these mammal assemblages have been partly replaced by exotic and non-forest dwelling species, so that the total species richness reflects the composite responses of all species across the meta-community (Hanski, 2015). In addition, due to the geometric effect (Bender et al., 1998) caused by both forest fragmentation and forest habitat loss, edge species, particularly those associated with the matrix and open areas, may have been favored and thus increased their
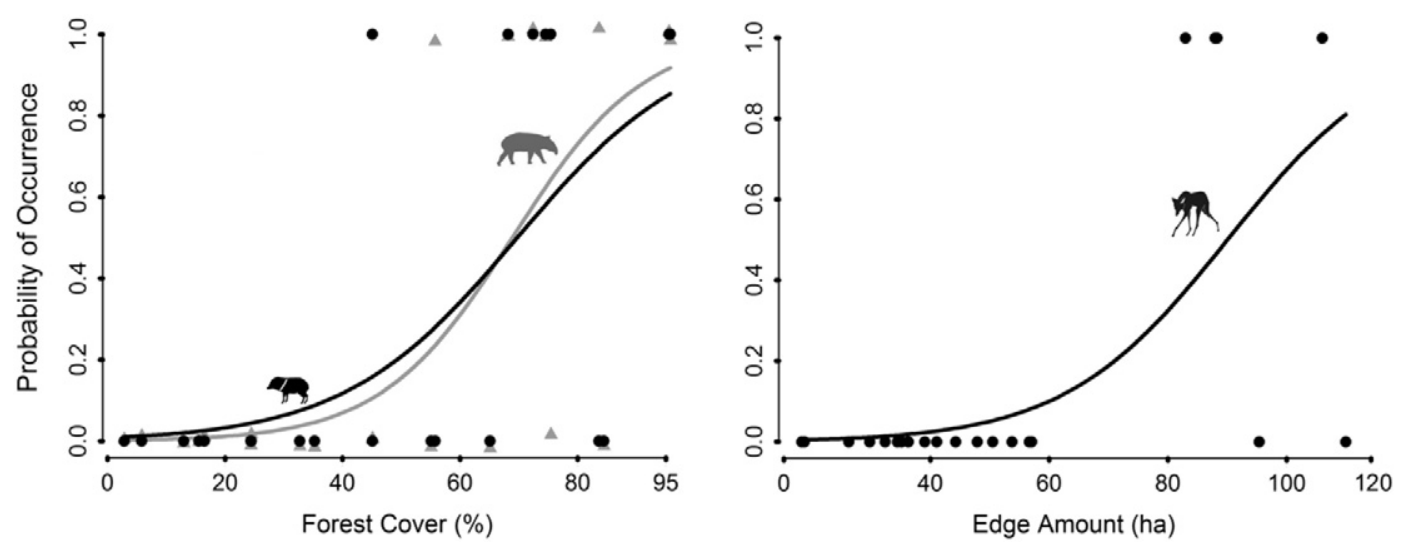

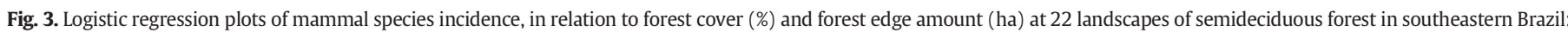
(A) Tapirus terrestris (gray triangles) and Pecari tajacu (solid circles), and (B) Chrysocyon brachyurus. 
population sizes in these landscapes (Prevedello et al., 2013; Ribeiro et al., 2015). So when we excluded aquatic habitat specialists, exotic, and non-forest dwelling species, we uncovered a plausible effect of forest cover and structural area on forest-specialists, thereby corroborating the species-area hypothesis (Chiarello, 1999; Pardini et al., 2010).

\subsection{Forest-specialist responses to habitat area}

The strictest forest-specialists among all terrestrial mammal species recorded, such as tapir, collared peccary and white-lipped peccary, were only recorded at landscapes containing over $45 \%$ of forest cover, indicating a possible minimum critical habitat amount threshold to ensure their occurrence. This relationship was also observed for white-lipped peccaries and tapirs, which are very sensitive to forest fragment size, predominantly occupying Atlantic Forest patches larger than 100,000 ha (Jorge et al., 2013) as long as they are not persecuted by hunters (Canale et al., 2012). The high dependence of forest habitats in these species is partly due to their highly frugivorous diet (O'Farrill et al., 2013; Galetti et al., 2015), which increases their spatial requirements (Keuroghlian et al., 2004). Other studies have also found minimum habitat size thresholds comparable to those uncovered in this study. For example, maintaining species richness of forest bats and small mammals in the Atlantic Forest and neighbouring biomes requires retention of at least $47 \%$ of forest cover (Estavillo et al., 2013; Muylaert et al., 2016).

\subsection{Species turnover and nestedness}

We found a high degree of species turnover $\left(\beta_{\text {sim }}\right)$ between landscapes, which represented approximately $95 \%$ of the overall $\beta$-diversity. This indicates that each landscape presents a fairly distinct subset of species, although agroecosystems typically retain a non-random set of species that often replaces core forest habitat and dietary specialists (Michalski and Peres, 2005; Lyra-Jorge et al., 2010). This species turnover was clearly influenced by overall forest cover, which can be associated with species-specific dispersal capacity (Qian, 2009), particularly of habitat generalists. Yet generalist species were more ubiquitous across multiple landscapes (Marvier et al., 2004), which facilitate their movements between different areas (Gatti et al., 2006; Lyra-Jorge et al., 2010). These species are also more likely to survive in fragmented landscapes (Gascon et al., 1999; Magioli et al., 2016), and represent the residual fauna in the aftermath of habitat fragmentation. For example, we found that the overall amount of forest edges best explained the occurrence of maned wolves, which is consistent with the patterns of open-habitat selection of this flagship cerrado species (Dietz, 1984), and their relatively low sensitivity to landscape change or disturbance (Devictor et al., 2008). Indeed, species typical of scrub savannas, such as maned wolf and brown brocket deer, appear to be expanding their geographic distribution into the semideciduous domain of the Atlantic Forest due to forest conversion into agricultural ecosystems (Coelho et al., 2008; Lyra-Jorge et al., 2010). Invasive domestic and exotic species may also change the composition of the biological community with the loss of native species in invaded areas (McKinney, 2004). Our findings indicate that this is associated with the widespread occurrence of domestic dogs within forest remnants, which have detrimental effects on native wildlife (Lessa et al., 2016). Exotic wild boars often occurred where large native ungulates were no longer present (Pedrosa et al., 2015), although the cause-effect relationships remain unclear (see Galetti et al., 2015).

\subsection{Conservation value of forest remnants immersed within biofuel plantations}

Neotropical forest remnants surrounded by sugarcane monoculture are significantly impoverished of their mammal fauna, as $60 \%$ of all species recorded were generalists, exotic or non-forest dwelling species.
Similar patterns have been found in other agricultural landscapes in Brazil (Dotta and Verdade, 2011; Gheler-Costa et al., 2012) and remnant lowland tropical forests of Southeast Asia surrounded by oil palm plantations (Bernard et al., 2009; Yue et al., 2015). These habitats are highly unfavorable to native mammal diversity, with species richness declining with distance from source forest fragments (Yue et al., 2015). Only about one quarter of all terrestrial forest-specialist species that we recorded were retained throughout all anthropogenic landscapes. However, these often small populations may persist for only a limited amount of time, since they may eventually pay an extinction debt due to suboptimal habitat conditions to support viable populations (Tilman et al., 1994; Haddad et al., 2015).

Our results indicate that local mammal assemblages have experienced a marked substitution of forest-specialists by generalists and exotic species, rather than a systematic process of biodiversity loss (Dornelas et al., 2014). This ensures that the regional species diversity is maintained, resulting in a similar species richness compared to large remnants. The same pattern of species substitution at large regional scale has been observed in birds in the same biome (Morante-Filho et al., 2016). However, it is critical that future studies strive to understand which effects the species turnover may have on future communities, especially regarding overall ecological functions, since generalist species tend to exhibit ecological redundancy (Olden et al., 2004).

Effective conservation measures in agricultural landscapes should explicitly consider biodiversity outcomes derived from more favorable scenarios, such as improving connectivity between neighbouring forest fragments (Magioli et al., 2016). The Brazilian Forest Bill, a group of laws that regulate land use and management of private properties, states that a forest strip of $30 \mathrm{~m}$ in width must be preserved along natural watercourses and that each rural property within the Atlantic forest domain required to set aside $20 \%$ of its area as natural vegetation (Brancalion et al., 2016). If widespread compliance with the Forest Bill had been enforced, most of our landscapes would be able to increase forest connectivity (Garcia et al., 2013) with no need to species introduction to establish important ecosystem services (Brodie and Aslan, 2012; Galetti et al., 2016b). Therefore, in such positive scenario where no extinction has been recorded at regional scale, the simply law compliance may restore the full assemblage of forest mammals even in hyper fragmented landscapes.

\section{Acknowledgements}

We thank the Fundação de Amparo à Pesquisa do Estado de São Paulo (FAPESP), Biota Program (2014/01986-0) for financial support. UNESP and COTEC/IF provided fieldwork infrastructure. We are grateful to S. Nazareth, C. Sanches, J.J. da Silva and F. Puertas for field assistance, and the landholders where our study was conducted. Also thanks to J.W. Ribeiro for helping in landscape metric calculations. G. Beca, M.H. Vancine, C. Carvalho, and F. Pedrosa received FAPESP fellowship (2014/23095-0, 2013/50421-2, 2014/01029-5 and 2015/18381-6 respectively). M Galetti and M.C. Ribeiro receive a research grant from CNPq (300241/2010-0 and 312045/2013-1 respectively). FAPESP also continuously supported M.C. Ribeiro (grant 2013/50421-2). A. Chiarello, L. Verdade and one anonymous reviewer for comments on an earlier version of the manuscript.

\section{Appendix A. Supplementary data}

Supplementary data to this article can be found online at http://dx. doi.org/10.1016/j.biocon.2017.02.033.

\section{References}

Andrén, H., 1994. Effects of habitat fragmentation on birds and mammals in landscapes with different proportions of suitable habitat: a review. Oikos 71, 355-366.

Banks-Leite, C., Pardini, R., Tambosi, L.R., Pearse, W.D., Bueno, A.A., Bruscagin, R.T., Condez, T.H., Dixo, M., Igari, A.T., Martensen, A.C., Metzger, J.P., 2014. Using ecological 
thresholds to evaluate the costs and benefits of set-asides in a biodiversity hotspot Science 345, 1041-1045.

Baselga, A., 2010. Partitioning the turnover and nestedness components of beta diversity. Glob. Ecol. Biogeogr. 19, 134-143.

Baselga, A., Orme, C.D.L., 2012. Betapart: an R package for the study of beta diversity. Methods Ecol. Evol. 3, 808-812.

Bender, D.J., Contreras, T.A., Fahrig, L., 1998. Habitat loss and population decline: a metaanalysis of the patch size effect. Ecology 79, 517-533.

Bennett, A.F., Radford, J.Q., Haslem, A., 2006. Properties of land mosaics: implications for nature conservation in agricultural environments. Biol. Conserv. 133, 250-264.

Benton, T.G., Bryant, D.M., Cole, L., Crick, H.Q.P., 2002. Linking agricultural practice to insect and bird populations: a historical study over three decades. J. Appl. Ecol. 39, 673-687.

Bernard, H., Fjeldsa, J., Mohamed, M., 2009. A case study on the effects of disturbance and conversion of tropical lowland rain forest on the non-volant small mammals in north Borneo: management implications. Mammal Study 34, 85-96.

Borcard, D., Gillet, F., Legendre, P., 2011. Numerical Ecology with R. Springer Science \& Business Media.

Brancalion, P.H., Garcia, L.C., Loyola, R., Rodrigues, R.R., Pillar, V.D., Lewinsohn, T.M., 2016. A critical analysis of the Native Vegetation Protection Law of Brazil 2012: updates and ongoing initiatives. Natureza \& Conservação 14, 1-15.

Brodie, J.F., Aslan, C.E., 2012. Halting regime shifts in floristically intact tropical forests deprived of their frugivores. Restor. Ecol. 20, 153-157.

Burnham, K.P., Anderson, D.R., 2002. Model Selection and Multi Model Inference: A Practical Information-Theoretic Approach. Springer Science \& Business Media.

Canale, G.R., Peres, C.A., Guidorizzi, C.E., Gatto, C.A.F., Kierulff, M.C.M., 2012. Pervasive defaunation of forest remnants in a tropical biodiversity hotspot. PLoS One 7, 1-9.

Ceballos, G., Ehrlich, P.R., Barnosky, A.D., García, A., Pringle, R.M., Palmer, T.M., 2015. Accelerated modern human-induced species losses: entering the sixth mass extinction. Sci. Adv. 1, e1400253.

Chiarello, A.G., 1999. Effects of fragmentation of the Atlantic forest on mammal communities in south-eastern Brazil. Biol. Conserv. 89, 71-82.

Chiarello, A.G., 2000. Conservation value of a native forest fragment in a region of extensive agriculture. Rev. Bras. Biol. 60, 237-247.

Coelho, C.M., Melo, F.B., Sábato, A.L., Magni, E.M.V., Hirsch, A., Young, R.J., 2008. Habitat use by wild maned wolves (Chrysocyon brachyurus) in a transition zone environment. J. Mammal. 89, 97-104

Cullen Jr., L., Bodmer, R.E., Valladares-Padua, C., Ballou, J.D., 2004. Mammalian densities and species extinctions in Atlantic forest fragments. In: Silvius, K.M., Bodmer, R.E. Fragoso, J.M. (Eds.), People in Nature: Wildlife Conservation in South and Central America. Columbia University Press, New York, pp. 211-226.

Devictor, V., Julliard, R., Jiguet, F., 2008. Distribution of specialist and generalist species along spatial gradients of habitat disturbance and fragmentation. Oikos 117, 507-514.

Dietz, J.M., 1984. Ecology and social organization of the maned wolf (Chrysocyon brachyurus). Smithsonian Contributions to Zoology 392, 1-51.

Dirzo, R., Young, H.S., Galetti, M., Ceballos, G., Isaac, N.J., Collen, B., 2014. Defaunation in the Anthropocene. Science 345, 401-406.

Donald, P.F., Green, R.E., Heath, M.F., 2001. Agricultural intensification and the collapse of Europes farmland bird populations. Proc. R. Soc. Lond. B Biol. Sci. 268, 25-29.

Dornelas, M., Gotelli, N.J., McGill, B., Shimadzu, H., Moyes, F., Sievers, C., Magurran, A.E., 2014. Assemblage time series reveal biodiversity change but not systematic loss. Science 344, 296-299.

Dotta, G., Verdade, L.M., 2011. Medium to large-sized mammals in agricultural landscapes of south-eastern Brazil. Mammalia 75, 345

Estavillo, C., Pardini, R., da Rocha, P.L.B., 2013. Forest loss and the biodiversity threshold: an evaluation considering species habitat requirements and the use of matrix habitats. PLoS One 8, 1-10.

Fahrig, L., 2013. Rethinking patch size and isolation effects: the habitat amount hypothesis. J. Biogeogr. 40, 1649-1663.

Fernández-Juricic, E., 2002. Can human disturbance promote nestedness? A case study with breeding birds in urban habitat fragments. Oecologia 131, 269-278.

Fortin, M.J., Dale, M.R.T., 2005. Spatial Analysis: A Guide for Ecologists. Cambridge University Press 365.

Galetti, M., Giacomini, H.C., Bueno, R.S., Bernardo, C.S.S., Marques, R.M., Bovendorp, R.S., Steffler, C.E., Rubim, P., Gobbo, S.K., Donatti, C.I., Begotti, R.A., Meirelles, F., Nobre, R.A., Chiarello, A.G., Peres, C.A., 2009. Priority areas for conservation of Atlantic Forest large mammals. Biol. Conserv. 142, 1229-1241.

Galetti, M., Camargo, H., Siqueira, T., Keuroghlian, A., Donatti, C.I., Jorge, M.L.S., Pedrosa, P. Kanda, C.Z., Ribeiro, M.C., 2015. Diet overlap and foraging activity between feral pigs and native peccaries in the Pantanal. PLoS One 10,1-10.

Galetti, M., Brocardo, C.R., Begotti, R.A., Hortenci, L., Rocha-Mendes, F., Bernardo, C.S.S., Bueno, R.S., Nobre, R., Bovendorp, R.S., Marques, R.M., Meirelles, F., Gobbo, S.K., Beca, G., Schmaedecke, G., Siqueira, T., 2016a. Defaunation and biomass collapse of mammals in the largest Atlantic forest remnant. Anim. Conserv.

Galetti, M., Pires, A.S., Brancalion, P.H., Fernandez, F.A., 2016b. Reversing defaunation by trophic rewilding in empty forests. Biotropica.

Garcia, L.C., Santos, J.S.D., Matsumoto, M., Silva, T.S.F., Padovezi, A., Sparovek, G., Hobbs, R.J., 2013. Restoration challenges and opportunities for increasing landscape connectivity under the new Brazilian Forest Act. Natureza e Conservação 11, 1-5.

Gascon, C., Lovejoy, T.E., Bierregaard Jr., R.O., Malcolm, J.R., Stouffer, P.C., Vasconcelos, H.L., Laurance, W.F., Zimmerman, B., Tocher, M., Borges, S., 1999. Matrix habitat and species richness in tropical forest remnants. Biol. Conserv. 91, 223-229.

Gatti, A., Bianchi, R., Rosa, C.R.X., Mendes, S.L., 2006. Diet of two sympatric carnivores, Cerdocyon thous and Procyon cancrivorus, in a resting area of Espírito Santo State, Brazil. J. Trop. Ecol. 22, 227-230.
Gheler-Costa, C., Vettorazzi, C.A., Pardini, R., Verdade, L.M., 2012. The distribution and abundance of small mammals in agroecosystems of southeastern Brazil. Mammalia 76, $185-191$.

Goslee, S.C., Urban, D.L., 2007. The ecodist package for dissimilarity-based analysis of ecological data. J. Stat. Softw. 22, 1-19.

Gotelli, N.J., Colwell, R.K., 2001. Quantifying biodiversity: procedures and pitfalls in the measurement and comparison of species richness. Ecol. Lett. 4, 379-391.

Green, R.E., Cornell, S.J., Scharlemann, J.P., Balmford, A., 2005. Farming and the fate of wild nature. Science 307, 550-555.

Haddad, N.M., Brudving, L.A., Clobert, J., Davies, K.F., Gonzalez, A., Holt, R.D., Lovejoy, T.E. Sexton, J.O., Austin, M.P., Collins, C.D., Cook, W.M., Damschen, E.I., Ewers, R.M., Foster, B.L., Jenkins, C.N., King, A.J., Laurance, W.F., Levey, D.J., Margules, C.R., Melbourne, B.A., Nicholls, A.O., Orrock, J.L., Song, D.S., Townshend, J.R., 2015. Habitat fragmentation and its lasting impact on Earth's ecosystems. Sci. Adv. 1, e1500052.

Hanski, I., 2015. Habitat fragmentation and species richness. J. Biogeogr. 42, 989-993.

Hijmans, R.J., 2016. raster: geographic data analysis and modeling. R package version. 2: 5-8. https://CRAN.R-project.org/package =raster.

Jorge, M.L.S.P., Galetti, M., Ribeiro, M.C., Ferraz, K.M.P.M.B., 2013. Mammal defaunation as surrogate of trophic cascades in a biodiversity hotspot. Biol. Conserv. 163, 49-57.

Keuroghlian, A., Eaton, D.P., Longland, W.S., 2004. Area use by white-lipped and collared peccaries (Tayassu pecari and Tayassu tajacu) in a tropical forest fragment. Biol. Conserv. 120, 411-425.

Kissinger, G., Herold, M., De Sy, V., 2012. Drivers of Deforestation and Forest Degradation: A Synthesis Report for REDD + Policymakers. Lexeme Consulting, Vancouver.

Kremsater, L., Bunnell, F.L., 1999. Edge effects: theory, evidence and implications to management of western North American forests. Forest Fragmentation: Wildlife and Management Implications, pp. 117-153.

Laurance, W.F., Lovejoy, T.E., Vasconcelos, H.L., Bruna, E.M., Didham, R.K., Stouffer, P.C., Gascon, C., Bierregaards, R.O., Laurance, S.G., Sampaio, E., 2002. Ecosystem decay of Amazonian forest fragments: a 22 year investigation. Conserv. Biol. 16, 605-618.

Lees, A.C., Peres, C.A., 2009. Gap-crossing movements predict species occupancy in Amazonian forest fragments. Oikos 118, 280-290.

Legendre, P., Legendre, L.F., 2012. Numerical Ecology. Elsevier.

Lessa, I., Guimarães, T.C.S., de Godoy Bergallo, H., Cunha, A., Vieira, E., 2016. Domestic dogs in protected areas: a threat to Brazilian mammals? Natureza \& Conservação 14, 46-56.

Lichstein, J.W., 2007. Multiple regression on distance matrices: a multivariate spatial analysis tool. Plant Ecol. 188, 117-131.

Lyra-Jorge, M.C., Ribeiro, M.C., Ciocheti, G., Tambosi, L.R., Pivello, V.R., 2010. Influence of multi-scale landscape structure on the occurrence of carnivorous mammals in human- modified savanna, Brazil. Eur. J. Wildl. Res. 56, 359-368.

Magioli, M., Ribeiro, M.C., Ferraz, K.M.P.M.B., Rodrigues, M.G., 2015. Thresholds in the relationship between functional diversity and patch size for mammals in the Brazilian Atlantic Forest. Anim. Conserv. 18, 499-3511.

Magioli, M., de Barros, K.M.P.M., Setz, E.Z.F., Percequillo, A.R., Rondon, M.V.D.S.S., Kuhnen, V.V., Canhoto, M.C.S., dos Santos, K.E.A., Kanda, C.Z., Fregonezi, G.L., Prado, H.A. Ferreira, M.K., Ribeiro, M.C., Villela, P.M.S., Coutinho, L.L., Rodrigues, M.C., 2016. Connectivity maintain mammal assemblages functional diversity within agricultural and fragmented landscapes. Eur. J. Wildl. Res. 62, 431-447.

Marvier, M., Kareiva, P., Neubert, M.G., 2004. Habitat destruction, fragmentation, and disturbance promote invasion by habitat generalists in a multispecies metapopulation. Risk Anal. 24, 869-878.

McKinney, M.L., 2004. Do exotics homogenize or differentiate communities? Roles of sampling and exotic species richness. Biol. Invasions 6, 495-504.

Michalski, F., Peres, C.A., 2005. Anthropogenic determinants of primate and carnivore local extinctions in a fragmented forest landscape of southern Amazonia. Biol Conserv. 124, 383-396.

Morante-Filho, J.C., Arroyo-Rodríguez, V., Faria, D., 2016. Patterns and predictors of $\beta$-diversity in the fragmented Brazilian Atlantic forest: a multiscale analysis of forest specialist and generalist birds. J. Anim. Ecol. 85, 240-250.

Muylaert, R.L., Stevens, R.D., Ribeiro, M.C., 2016. Threshold effect of habitat loss on bat richness in cerrado-forest landscapes. Ecol. Appl.

O'Farrill, G., Galetti, M., Campos-Arceiz, A., 2013. Frugivory and seed dispersal by tapirs: an insight on their ecological role. Integrative Zoology 8, 4-17.

Oksanen, J., Blanchet, F.G., Kindt, R., Legendre, P., Minchin, P.R., O'Hara, R.B., Wagner, H. 2013. Package 'vegan'. R Package. 254, pp. 20-28.

Olden, J.D., Poff, N.L, Douglas, M.R., Douglas, M.E., Fausch, K.D., 2004. Ecological and evolutionary consequences of biotic homogenization. Trends Ecol. Evol. 19, 18-24.

Pardini, R., Bueno, A.D.A., Gardner, T.A., Prado, P.I., Metzger, J.P., 2010. Beyond the fragmentation threshold hypothesis: regime shifts in biodiversity across fragmented landscapes. PLoS One 5, 1-10.

Paviolo, A., de Angelo, C., Ferraz, K.M.P.M.B., Morato, R.G., Pardo, J.M., Srbek-Araujo, A.C., Beisiegel, B.M., Lima, F., Sana, D., da Silva, M.X., Velázquez, M.C., Cullen, L. Crawshaw Jr., P., Jorge, M.L.S.P., Galetti, M.P., Di Bitetti, M.S., de Paula, R.C., Eizirik, E., Aide, T.M., Cruz, P., Perilli, M.L.L., Souza, A.S.M., Quiroga, V., Nakano, E., Pinto, F.R., Fernández, S., Costa, S., Moraes Jr., E.A. Azevedo, F., 2016. A biodiversity hotspot losing its top predator: the challenge of jaguar conservation in the Atlantic Forest of South America. Sci. Report. 6.

Pedrosa, F., Salerno, R., Padilha, F.V.B., Galetti, M., 2015. Current distribution of invasive feral pigs in Brazil: economic impacts and ecological uncertainty. Natureza \& Conservação 13, 84-87.

Prevedello, J.A., Figueiredo, M.S., Grelle, C.E., Vieira, M.V., 2013. Rethinking edge effects: the unaccounted role of geometric constraints. Ecography 36, 287-299.

Qian, H., 2009. Beta diversity in relation to dispersal ability for vascular plants in North America. Glob. Ecol. Biogeogr. 18, 327-332.

Ribeiro, M.C., Metzger, J.P., Martensen, A.C., Ponzoni, F.J., Hirota, M.M., 2009. The Brazilian Atlantic Forest: how much is left, and how is the remaining forest distributed? Implications for conservation. Biol. Conserv. 142, 1141-1153. 
Ribeiro, S.E., Prevedello, J.A., Delciellos, A.C., Vieira, M.V., 2015. Edge effects and geometric constraints: a landscape-level empirical test. J. Anim. Ecol. 85, 97-105.

Ribeiro, M.C., Muylaert, R.L., Dodonov, P., Ciocheti, G., Magioli, M., Martello, F., Rocha, A. Borges, B.D., Carvalho, C., Kanda, C.Z., Rodriguez-Castro, K.G., 2016. Dealing with fragmentation and road effects in highly degraded and heterogeneous landscapes. In: Gheler-Costa, C., Lyra-Jorge, M.C., Verdade, L.M. (Eds.), Biodiversity in Agricultural Landscapes of Southeastern Brazil. 4. Warsaw/Berlin: de Gruyter Open, pp. 43-64.

Rocha, G.P., Vieira, D.L., Simon, M.F., 2016. Fast natural regeneration in abandoned pastures in southern Amazonia. For. Ecol. Manag. 370, 93-101.

Salis, S.M., Shepherd, G.J., Joly, C.A., 1995. Floristic comparisons of Mesophytic semideciduous forests of the interior of the State of Sao Paulo, Southeast Brazil. Vegetatio 119, 155-164.

Schipper, J., Chanson, J., Chiozza, F., Cox, N., Hoffmann, M., Katariya, V., Lamoureux, J., Rodrigues, A.S.L., Stuart, S.N., Temple, H.J., Baillie, J.E.M., Boitani, L., Lacher, T.E. Mittermeier, R.A., Smith, A.T., Absolon, D., Aguiar, J.M., Amori, G., Bakkour, N., Baldi, R.A., Berridge, R.J., Bielby, J., Black, P.A., Blanc, J.J., Brooks, T.M., Burton, J.A., Butynski, T.M., Catullo, G., Chapman, R., Cokeliss, Z., Collen, B., Conroy, J., Cooke, J.G., da Fonseca, G.A.B., Derocher, A.E., Dublin, H.T., Duckworth, J.W., Emmons, L., Emslie, R.H., Festa-Bianchet, M., Foster, M., Foster, S.N., Garshelis, D.L., Gates, C., GimenezDixon, M., Gonzalez, S., Gonzalez-Maya, J.F., Good, T.C., Hammerson, G., Hammond P.S., Happold, D., Happold, M., Hare, J., Harris, R.B., Hawkins, C.E., Haywood, M., Heaney, L., Hedges, S., Helgen, K.M., Hilton-Taylor, C., Hussain, S.A., Ishii, N., Jefferson, T.A., Jenkins, R.K.B., Johnston, C.H., Keith, M., Kingdon, J., Knox, D., Kovacs, K.M., Langhammer, P., Leus, K.M., Lewison, R., Lichtenstein, G., Lowry, L.F., Macavoy, Z., Mace, G.M., Mallon, D.P., Masi, M., Mcknight, M.W., Medellin, R., Medici, P., Mills, G., Moehlman, P.D., Molur, S., Mora, A.E., Nowell, K., Oates, J.F., Olech, W., Oliver, W.L.R., Oprea, M., Patterson, B., Perrin, W.F., Polidoro, B.A., Pollock, C., Powel, A. Protas, Y., Racey, P.A., Ragle, J., Ramani, P., Rathbun, G., Reeves, R.R., Reilly, S.B. Reynolds III, J.E., Rondinini, C., Rulli, M., Rylands, A.B., Savini, S., Schank, C.J., Sechrest, W., Self-Sullivan, C., Shoemaker, A., Sillero-Zubiri, C., Silva, N., Smith, D.E. Srinivasulu, C., Stephenson, P.J., VanStrien, N., Talukdar, B.K., Taylor, B.L., Timmins, R., Tirira, D.G., Tognelli, M.F., Tsytsulina, K., Veiga, L.M., Vie, J.C., Williamson, L. Wyatt, S.A., Xie, Y., Young, B.E., 2008. The status of the world's land and marine mammals: diversity, threat, and knowledge. Science 322, 225-230.
Smith, C.D., Pontius, J.S., 2006. Jackknife estimator of species richness with S-PLUS. J. Stat. Softw. 15, 1-12.

Soares-Filho, B.S., Rajão, R., Merry, F., Rodrigues, H., Davis, J., Lima, L., Macedo, M., Coe, M., Carneiro, A., Santiago, L., 2016. Brazil's Market for trading forest certificates. PLoS One 1, e0152311.

Srbek-Araujo, A.C., Chiarello, A.G., 2005. Is camera-trapping an efficient method for surveying mammals in Neotropical forests? A case study in south-eastern Brazil. J. Trop. Ecol. 21, 121-125.

Tabarelli, M., Da Silva, M.J.C., Gascon, C., 2004. Forest fragmentation, synergisms and the impoverishment of Neotropical Forests. Biodivers. Conserv. 13, 1419-1425.

Tabarelli, M., Peres, C.A., Melo, F.P.L., 2012. The 'few winners and many losers' paradigm revisited: emerging prospects for tropical forest biodiversity. Biol. Conserv. 155, 136-140.

Tilman, D., May, R.M., Lehman, C.L., Nowak, M.A., 1994. Habitat destruction and the extinction debt. Nature 371, 65-66.

Tobler, M.W., Carrillo-Percastegui, S.E., Leite-Pitman, R., Mares, R., Powell, G., 2008. An evaluation of camera traps for inventorying large-and medium-sized terrestrial rainforest mammals. Anim. Conserv. 11, 169-178.

Tscharntke, T., Klein, A.M., Steffan-Dewenter, I., Thies, C., 2005. Landscape perspectives on agricultural intensification and biodiversity - ecosystem service management. Ecol. Lett. 8, 857-874.

Turner, W.R, Brandon, K, Brooks, T.M., Costanza, R., da Fonseca, G.A.B, Portela, R, 2007. Global conservation of biodiversity and ecosystem services. Bioscience 57, 868-873.

Wearn, O.R., Carbone, C., Rowcliffe, J.M., Bernard, H., Ewers, R.M., 2016. Grain-dependent responses of mammalian diversity to land-use and the implications for conservation set-aside. Ecol. Appl. 26, 1409-1420.

Young, H.S., McCauley, D.J., Galetti, M., Dirzo, R., 2016. Patterns, causes, and consequences of anthropocene defaunation. Annu. Rev. Ecol. Evol. Syst. 47, 333-358.

Yue, S., Brodie, J.F., Zipkin, E.F., Bernard, H., 2015. Oil palm plantations fail to support mammal diversity. Ecol. Appl. 25, 2285-2292.

Zar, J.H., 2010. Biostatistical Analysis. 5th.ed. 663. Prentice Hall, New Jersey.

Zuur, A., Ieno, E.N., Walker, N., Saveliev, A.A., Smith, G.M., 2009. Mixed Effects Models and Extensions in Ecology with R. Springer Science \& Business Media. 